\title{
Elevated Krüppel-like factor 4 transcription factor in canine mammary carcinoma
}

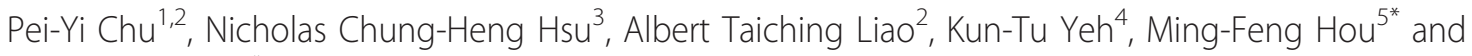

Chen-Hsuan Liu ${ }^{2 *}$

\begin{abstract}
Background: Krüppel-like factors (KLFs) are critical regulators of biological and physiological systems and have been extensively studied for their roles in cell proliferation, differentiation and survival in the context of cancer. Among the KLFs, KLF4 is highly expressed in human breast cancers and plays an oncogenic role. The present study examined the expression of KLF4 and assessed its significance in canine mammary carcinoma.

Results: Immunohistochemistry was employed to investigate the expression of KLF4 in 142 cases of canine mammary tumor. 75 of the 142 (52.8\%) cases were histologically confirmed as mammary carcinoma. Quantification of immunohistochemistry was carried out using Quick score which multiply the staining intensity by the percentage of positive cells. High KLF4 expression was identified in 44 of the 75 (59\%) dogs with mammary carcinoma and none in the benign cases. High KLF4 expression occurred only in the tumor cells and not the adjacent normal cells in mammary carcinoma ( $<$ < 0.001). Moreover, the high expression level of KLF4 expression was statistically associated with poor grade, late stage, histological subtypes of simple and complex carcinoma, and shorter 24-month survival. The Kaplan-Meier survival analysis also indicated that dogs with high nuclear KLF4 expression had a significantly shorter survival than those with low/moderate KLF4 expression $(P=0.011)$.
\end{abstract}

Conclusions: KLF4 is highly and frequently expressed in canine mammary carcinoma and correlates with a more aggressive phenotype.

\section{Background}

Canine mammary tumors are the most common tumor in female dogs. The spontaneous, naturally occurring canine mammary tumors share many features with human breast cancer such as the predominant malignant histological type being adenocarcinoma [1-3] and the expression of estrogen and progesterone receptors (ER/ $\mathrm{PR}$ ), and epidermal growth factor receptor 2 (HER2) in subsets of canine mammary carcinoma [4-7]. It has been suggested that canine mammary carcinomas may be a suitable natural model for the comparative study of human breast cancer [4,5,7-9].

The Krüppel-like factor (KLF) family proteins are transcription factors that play important roles in a wide

\footnotetext{
* Correspondence: mifeho@kmu.edu.tw; chhsuliu@ntu.edu.tw

${ }^{2}$ Department and Graduate Institute of Veterinary Medicine, School of Veterinary Medicine, National Taiwan University, No. 1, Section 4, Roosevelt Road, Taipei, 10617, Taiwan

${ }^{5}$ Cancer Center, Kaohsiung Medical University Hospital, No. 100, Tzyou 1st Road, Kaohsiung, 80708, Taiwan

Full list of author information is available at the end of the article
}

range of cellular processes, including embryogenesis, proliferation, differentiation, migration, inflammation and tumorigenesis [10-13].

The KLF family consists of 17 different members in which many have been identified as potentially novel oncogenes or tumor suppressors [13,14]. Human KLF4 was first identified using a DNA probe containing the zinc finger region of human erythroid Krüppel-like factor from human umbilical vein endothelial cell cDNA library [15]. The biological effects of KLF4 seem to depend on cancer type rather than unique. KLF4 transcription factor can function as a tumor suppressor and is down-regulated in various human cancer types such as gastric and colorectal cancer [16,17]. On the other hand, high level and oncogenic role of KLF4 were also reported in human breast cancer and oral squamous carcinoma $[18,19]$. This study investigated the presence of KLF4 and established their clinical significance in canine mammary carcinoma.

\section{Biomed Central}




\section{Results}

One hundred forty-two dogs (43 Maltese, 11 Yorkshire terriers, 11 Shih-Tzus, 9 Pomeranians, 10 Cocker spaniels, 2 French spaniels, 2 Bichon Frisé, 7 poodles, 2 German shepherd dogs, 1 Shiba, 3 Beagles, 1 Labrador Retriever, 1 Husky, 1 Miniature Doberman, 1 Papillon, 1 Schnauzer, 1 Spitz, and 35 mongrels) were investigated in this study. Of the 142 cases, $52.8 \%$ (75/142) were histologically confirmed as carcinoma.

Analyzing the expression of KLF4 in paraffin-embedded tissues by IHC revealed up-regulated nuclear KLF4 expression in mammary carcinomas as compared to benign tumor cases (Table 1). We divided carcinoma patients into three groups, either high KLF4 expression with Quick score of 9-12, moderate KLF4 expression with Quick score of 5-8, or weak KLF4 expression with Quick score of 1-4 (Figure 1). High expression of KLF4 (as defined by a Quick score of 9 or greater) was identified in 59\% (44/75) of dogs with mammary carcinoma and none in the benign tumors. Moreover, high expression level of KLF4 occurred preferentially in the tumor cells and not the adjacent nontumor cells in mammary carcinoma $(\mathrm{P}<0.001$, Table 2 and Figure 2). Chi-square analyses for the clinicopathologic characteristics of the 75 canine mammary carcinoma cases in relation to nuclear KLF4 expression showed that high KLF4 expression correlated significantly with shorter 24-month survival $(P=0.01$, Table 3$)$. High KLF4 expression was also closely associated with poor grade, late stage, and histological subtypes of simple and complex carcinoma. The Kaplan-Meier survival curves indicated that patients with high nuclear expression of KLF4 had a significantly poor survival than those with low/moderate KLF4 expression as defined by log-rank test $(\mathrm{P}=0.011$, Figure 3).

\section{Discussion}

Studies of KLF proteins in mouse models of human diseases have revealed the normal biological roles of the KLFs as well as their involvement in the pathogenesis of a variety of diseases such as cancer [20]. Previous studies have shown that approximately $70 \%$ of human breast cancer has increased KLF4 expression and that up-regulated nuclear KLF4 expression is associated with a more aggressive phenotype $[18,21]$. The oncogenic properties of KLF4 in breast cancers was also confirmed in vitro and using

\begin{tabular}{|c|c|c|c|c|c|}
\hline \multirow[b]{2}{*}{ Histological classification } & \multicolumn{4}{|c|}{ Quick score } & \multirow[b]{2}{*}{ total } \\
\hline & 0 & $1-4$ & $5-8$ & $9-12$ & \\
\hline Benign tumor & 0 & 60 & 7 & 0 & 67 \\
\hline Carcinoma & 0 & 12 & 19 & 44 & 75 \\
\hline
\end{tabular}

xenograft tumor model in which KLF4 knockdown inhibited breast cancer development [22].

The breast cancer stem cell hypotheses suggest that breast cancer is derived from a single cell with stem-like properties that is capable of tumor initiation and formation. KLF4 can inhibit differentiation and increase selfrenewal in embryonic stem (ES) cells [23,24]. Forced expression of KLF4, along with transcription factors, Oct4, c-myc, and Sox2, can reprogram or dedifferentiate somatic cells into

induced pluripotent stem cells (iPSCs) in both mice [25,26] and human [27-29]. Taken together, these finding suggest that KLF4 is indispensable for the regulation of stem cells and contributes to tumorigenesis.

In this study, we investigated the expression and clinical relevance of KLF4 in canine mammary carcinoma. Immunihistochemistry revealed that nuclear expression of KLF4 was elevated in tumor cells of canine mammary carcinoma. Although increased KLF4 expression was not related to prognostic markers such as ER, PR or HER2. High nuclear KLF4 expression was associated significantly with a more aggressive phenotype as indicated by poor grade, late stage, histological subtypes of simple and complex carcinoma, and shorter 24-month survival in canine mammary carcinoma. Despite diffuse cytoplasmic KLF4 expression with different degree of intensity was observed among the samples. The cytoplasmic KLF4 expression was not related to any clinicopathologic parameters and survival (data not shown). The Kaplan-Meier survival analysis also indicated that dogs with high nuclear expression of KLF4 had a significantly shorter survival as compared with ones with low/moderate nuclear KLF4 expression.

We provided evidence for the first time that KLF4 is preferentially and highly expressed in canine mammary carcinoma. As in human breast cancer, KLF4 plays an oncogenic role in canine mammary carcinoma. Further studies are needed to validate whether systemic targeting of KLF4 would inhibits the oncogenic functions of KLF4 thus provides an effective strategy for the treatment of canine mammary carcinoma.

\section{Conclusions}

Nuclear expression of KLF4 is frequently elevated in canine mammary carcinoma and closely correlated with a more aggressive phenotype and shorter survival.

\section{Methods \\ KLF4 Immunohistochemistry}

Paraffin-embedded tissue blocks of 142 cases of canine mammary tumor diagnosed between January 2003 and April 2008 were retrieved from the archives of the School of Veterinary Medicine, National Taiwan University, Taiwan. The tumors were diagnosed according to the WHO criteria for canine mammary neoplasms [30]. Samples 


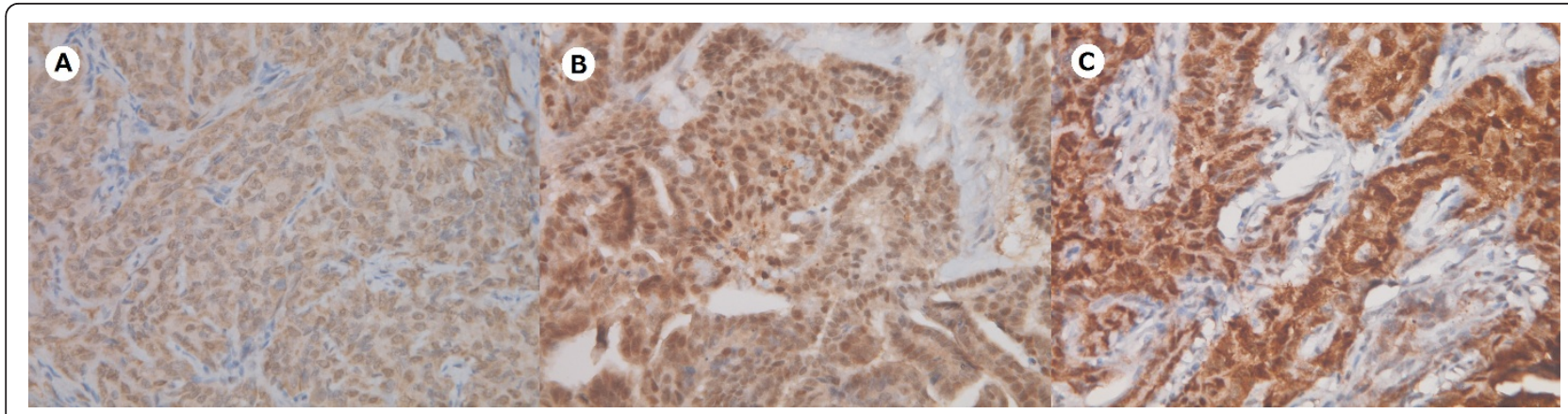

Figure 1 Representative immunohistochemical staining patterns of KLF4 in canine mammary carcinoma $(\times 400)$. (A) weak (B) moderate (C) strong nuclear KLF4 expression.

were first de-waxed in xylene and re-hydrated through graded alcohols, followed by a rinse using $10 \mathrm{mM}$ Tris$\mathrm{HCl}(\mathrm{pH} 7.4)$ and $150 \mathrm{mM}$ sodium chloride, then treated with 3\% hydrogen peroxide for $5 \mathrm{~min}$. Slides were incubated with 1:250 dilution of anti-KLF4 antibody (sc-20691, Santa Cruz Biotechnology, USA) for 1 hour at room temperature, then thoroughly washed three times with PBS. Bound antibodies were detected using the LSAB+ kit (Dako, USA). The slides were then counterstained with haematoxylin stain solution. Paraffin-embedded sections of human breast cancer cells of homogeneous KLF4 immunophenotype were included as positive controls. Negative controls had the primary antibody omitted and replaced by PBS. Quantification of KLF4 expression was carried out using Quick score which multiply the staining intensity by the percentage of positive cells [31-33]. The intensity of staining was scored as $0,1,2$, and 3 standing for negative, weak, moderate, and strong staining, respectively. The percentage of tumor cells staining positively was scored as follows: $0=0 \%, 1=1-25 \%, 2=26-50 \%, 3=$ $51-75 \%$, and $4=76-100 \%$, compared with the total of tumor cells. The immunohistochemical results were evaluated by two investigators scoring independently. Conflicting scores were resolved at a dual head microscope.

\section{Molecular Phenotyping}

Immunohistochemistry was performed in parallel as described above with monoclonal antibodies for ER (1:35 dilution, Dako, Denmark), PR (1:200 dilution,

Table 2 Expression of KLF4 in canine mammary tumor

\begin{tabular}{lccccc}
\hline & & \multicolumn{2}{c}{ Pathological diagnosis } & & \\
\cline { 2 - 4 } KLF4 expression & Benign tumor & Carcinoma & Total & P \\
\hline Tumor part & & & & & \\
Quick score & $<9$ & $67(100 \%)$ & $31(41.3 \%)$ & 98 & $<0.001$ \\
& $\geqq 9$ & 0 & $44(58.7 \%)$ & 44 & \\
\multicolumn{2}{c}{ Non-tumor part } & & & & \\
Quick score & $<9$ & $67(100 \%)$ & $75(100 \%)$ & 142 & N/A \\
& $\geqq 9$ & 0 & 0 & 0 & \\
\hline
\end{tabular}

Thermo Scientific, USA), HER2 (1:400 dilution, Dako, Denmark), CK5 (1:100 dilution, Novacastra, UK), and Pcadherin (1:100 dilution, Novacastra, UK). ER and PR immunoreactivity was considered positive when more than $10 \%$ of the neoplastic cells expressed this marker [5]. HercepTest scoring system was applied to evaluate HER2 expression $(0=$ no staining or membrane staining in fewer than $10 \%$ of tumor cells; $1+=$ faint, barely perceptible membrane staining in more than $10 \%$ of tumor cells; $2+=$ weak to moderate complete membrane staining observed in more than $10 \%$ of tumor cells; $3+=$ strong and complete membrane staining in more than $10 \%$ tumor cells) [5]. In this study, overexpression of HER2 was defined as a HercepTest score of 3+. As for CK5 and P-cadherin, cytoplasmic staining in $>50 \%$ of cells was considered positive [5]. Immunohistochemical panel which involved the evaluation of ER, HER2, CK5, and P-cadherin was used to distinguish canine mammary carcinoma subtypes $[5,34]$.

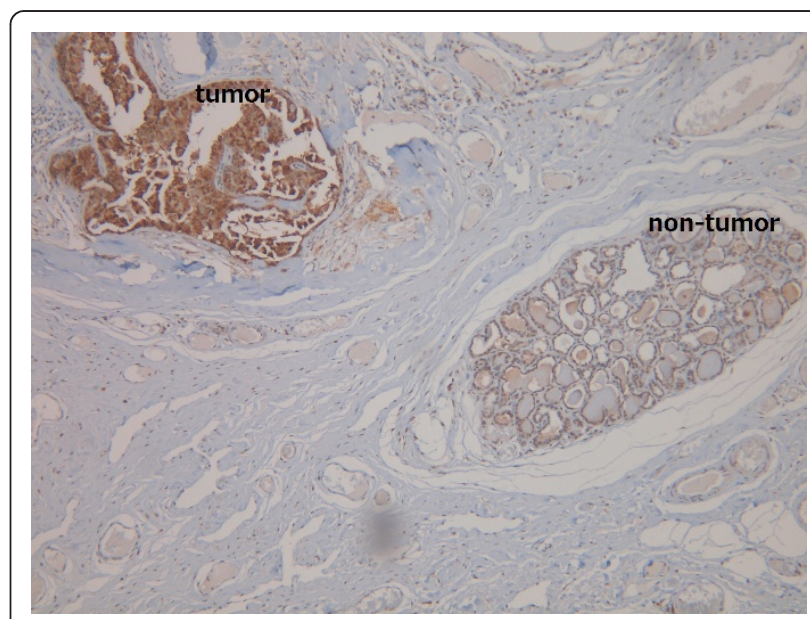

Figure 2 Elevated KLF4 expression identified in tumor cells and not adjacent non-tumor cells in a representative canine mammary carcinoma (40X) 
Table 3 Clinicopathologic characteristics of canine mammary carcinoma

\begin{tabular}{|c|c|c|c|c|c|c|}
\hline & \multicolumn{4}{|c|}{ KLF4 expression (Quick score) } & \multirow{3}{*}{$\mathbf{N}$} & \multirow{3}{*}{$P$} \\
\hline & \multicolumn{2}{|c|}{ low/moderate $(<9)$} & \multicolumn{2}{|c|}{ High $(\geqq 9)$} & & \\
\hline & $\mathrm{n}$ & $\%$ & $\mathrm{n}$ & $\%$ & & \\
\hline \multicolumn{7}{|l|}{$\overline{\text { Age }}$} \\
\hline$<12$ years & 14 & $45.2 \%$ & 17 & $38.6 \%$ & 31 & 0.572 \\
\hline$\geqq 12$ years & 17 & $54.8 \%$ & 27 & $61.4 \%$ & 44 & \\
\hline \multicolumn{7}{|l|}{ Ovariohysterectomy } \\
\hline No & 26 & $83.9 \%$ & 33 & $75.0 \%$ & 59 & 0.356 \\
\hline Yes & 5 & $16.1 \%$ & 11 & $25.0 \%$ & 16 & \\
\hline \multicolumn{7}{|l|}{ Tumor Size } \\
\hline $\mathrm{T} 1(<3 \mathrm{~cm})$ & 15 & $48.4 \%$ & 11 & $25.0 \%$ & 26 & \\
\hline $\mathrm{T} 2(\geqq 3 \mathrm{~cm},<5 \mathrm{~cm})$ & 7 & $22.6 \%$ & 18 & $40.9 \%$ & 25 & 0.089 \\
\hline $\mathrm{T} 3(>5 \mathrm{~cm})$ & 9 & $29.0 \%$ & 15 & $34.1 \%$ & 24 & \\
\hline \multicolumn{7}{|l|}{ Grade } \\
\hline । & 12 & $38.7 \%$ & 5 & $11.4 \%$ & 17 & \\
\hline$\|$ & 14 & $45.2 \%$ & 22 & $50.0 \%$ & 36 & 0.009 \\
\hline III & 5 & $16.1 \%$ & 17 & $38.6 \%$ & 22 & \\
\hline \multicolumn{7}{|l|}{ Histological classification } \\
\hline Carcinoma in benign tumor & 5 & $16.1 \%$ & 0 & $0.0 \%$ & 5 & \\
\hline Complex carcinoma & 14 & $45.2 \%$ & 21 & $47.7 \%$ & 35 & 0.020 \\
\hline Simple carcinoma & 12 & $38.7 \%$ & 23 & $52.3 \%$ & 35 & \\
\hline \multicolumn{7}{|l|}{ Location of affected gland } \\
\hline cranial & 10 & $32.3 \%$ & 17 & $38.6 \%$ & 27 & 0.571 \\
\hline caudal & 21 & $67.7 \%$ & 27 & $61.4 \%$ & 48 & \\
\hline \multicolumn{7}{|l|}{ Stage } \\
\hline । & 15 & $48.4 \%$ & 5 & $11.4 \%$ & 20 & \\
\hline$\|$ & 5 & $16.1 \%$ & 13 & $29.5 \%$ & 18 & \\
\hline III & 4 & $12.9 \%$ & 7 & $15.9 \%$ & 11 & 0.006 \\
\hline IV & 4 & $12.9 \%$ & 15 & $34.1 \%$ & 19 & \\
\hline V & 3 & $9.7 \%$ & 4 & $9.1 \%$ & 7 & \\
\hline \multicolumn{7}{|l|}{$E R$} \\
\hline Negative & 16 & $51.6 \%$ & 23 & $52.3 \%$ & 39 & 0.955 \\
\hline Positive & 15 & $48.4 \%$ & 21 & $47.7 \%$ & 36 & \\
\hline \multicolumn{7}{|l|}{$P R$} \\
\hline Negative & 6 & $19.4 \%$ & 5 & $11.4 \%$ & 11 & 0.509 \\
\hline Positive & 25 & $80.6 \%$ & 39 & $88.6 \%$ & 64 & \\
\hline \multicolumn{7}{|l|}{ Her-2/neu } \\
\hline Negative & 26 & $83.9 \%$ & 32 & $72.7 \%$ & 58 & 0.281 \\
\hline Positive & 5 & $16.1 \%$ & 12 & $27.3 \%$ & 17 & \\
\hline \multicolumn{7}{|l|}{ Molecular phenotyping } \\
\hline Basal & 10 & $32.3 \%$ & 15 & $34.1 \%$ & 25 & \\
\hline HER-2 overexpressing & 2 & $6.5 \%$ & 5 & $11.4 \%$ & 7 & \\
\hline Luminal A & 12 & $38.7 \%$ & 14 & $31.8 \%$ & 26 & 0.761 \\
\hline Luminal B & 3 & $9.7 \%$ & 7 & $15.9 \%$ & 10 & \\
\hline Null & 4 & $12.9 \%$ & 3 & $6.8 \%$ & 7 & \\
\hline \multicolumn{7}{|l|}{ Survival ${ }^{a}$} \\
\hline$<24$ months & 9 & $56.3 \%$ & 34 & $89.5 \%$ & 43 & 0.010 \\
\hline$\geqq 24$ months & 7 & $43.8 \%$ & 4 & $10.5 \%$ & 11 & \\
\hline
\end{tabular}

${ }^{a}$ Twenty-one cases lacked survival data and were excluded from the analysis. 


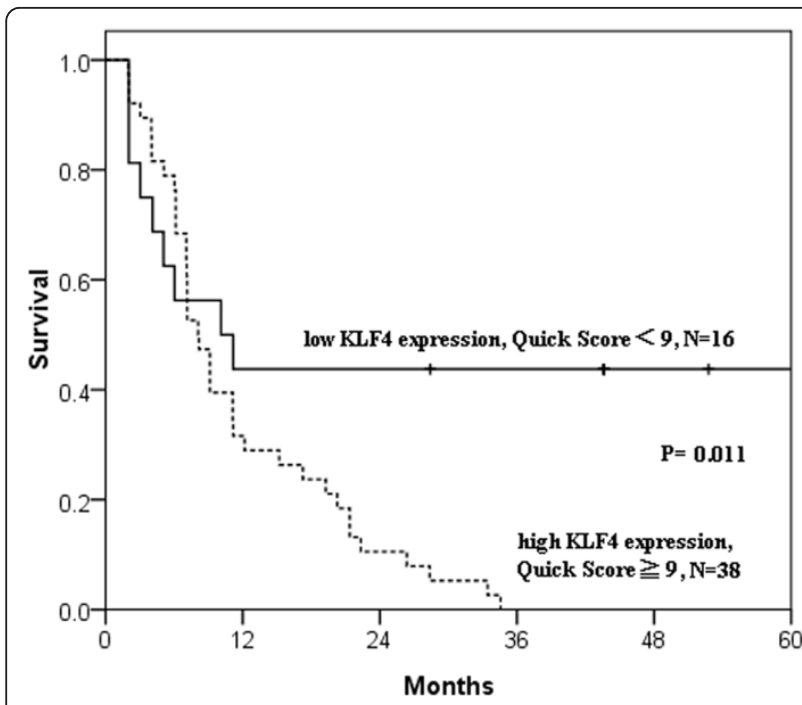

Figure 3 The Kaplan-Meier plots for survival according to high versus low/moderate nuclear KLF4 expression. Twenty-one case lacked survival data and were excluded from the analysis.

\section{Statistical Analysis}

Overexpression of KLF4 was defined as a Quick score of 9 or greater on the scale of 0 to 12. Patterns and correlations of KLF4 and clinicopathologic parameters of canine mammary tumor were examined by Pearson's chi-square test. Survival rate was calculated using Kaplan-Meier analysis and compared by the Cochran-Mantel-Haenszel test (logrank test). Survival was defined as the time between date of diagnosis and date of death. Subjects still alive at the end of the study were censored at the date of last followup. Cases that lacked survival information were excluded from the analysis. A P value of less than 0.05 was considered to indicate statistical significance.

\section{Acknowledgements}

This study was supported by a grant from the Department of Health, Taiwan (DOH100-TD-C-111-002).

\section{Author details}

'Department of Pathology, St. Martin De Porres Hospital, No. 565, Section 2, Daya Road, Chiayi, 60069, Taiwan. ${ }^{2}$ Department and Graduate Institute of Veterinary Medicine, School of Veterinary Medicine, National Taiwan University, No. 1, Section 4, Roosevelt Road, Taipei, 10617, Taiwan. ${ }^{3}$ Graduate Institute of Medicine, Kaohsiung Medical University, No. 100, Shih-Chuan 1st Road, Kaohsiung, 80708, Taiwan. ${ }^{4}$ Department of Pathology, Changhua Christian Hospital, No. 135, Nanxiao Street, Changhua, 500, Taiwan. ${ }^{5}$ Cancer Center, Kaohsiung Medical University Hospital, No. 100, Tzyou 1st Road, Kaohsiung, 80708, Taiwan.

\section{Authors' contributions}

PYC drafted the manuscript, NCH performed the statistical analysis, ATL and KTY carried out the immunohistochemical staining, MFH and CHL designed the study. All authors read and approved the final manuscript.

Received: 1 July 2011 Accepted: 7 October 2011

Published: 7 October 2011

\section{References}

1. Cotchin E: Mammary neoplasms of the bitch. J Comp Pathol 1958, 68(1):1-22.

2. Moulton JE, Taylor DO, Dorn CR, Andersen AC: Canine mammary tumors. Pathol Vet 1970, 7(4):289-320.

3. Prier JE, Brodey RS: Canine Neoplasia. A Prototype for Human Cancer Study. Bull World Health Organ 1963, 29:331-344.

4. Ferreira E, Gobbi H, Saraiva BS, Cassali GD: Columnar cell lesions of the canine mammary gland: pathological features and immunophenotypic analysis. BMC Cancer 2010, 10:61.

5. Gama A, Alves A, Schmitt F: Identification of molecular phenotypes in canine mammary carcinomas with clinical implications: application of the human classification. Virchows Arch 2008, 453(2):123-132.

6. Mouser P, Miller MA, Antuofermo E, Badve SS, Mohammed SI: Prevalence and classification of spontaneous mammary intraepithelial lesions in dogs without clinical mammary disease. Vet Pathol 2010, 47(2):275-284.

7. Vinothini G, Balachandran C, Nagini S: Evaluation of molecular markers in canine mammary tumors: correlation with histological grading. Oncol Res 2009, 18(5-6):193-201.

8. Martin PM, Cotard M, Mialot JP, Andre F, Raynaud JP: Animal models for hormone-dependent human breast cancer. Relationship between steroid receptor profiles in canine and feline mammary tumors and survival rate. Cancer Chemother Pharmacol 1984, 12(1):13-17.

9. Strandberg JD, Goodman DG: Animal model of human disease: canine mammary neoplasia. Am J Pathol 1974, 75(1):225-228.

10. Huang CC, Liu Z, Li X, Bailey SK, Nail CD, Foster KW, Frost AR, Ruppert JM, Lobo-Ruppert SM: KLF4 and PCNA identify stages of tumor initiation in a conditional model of cutaneous squamous epithelial neoplasia. Cancer Biol Ther 2005, 4(12):1401-1408.

11. Segre JA, Bauer C, Fuchs E: Klf4 is a transcription factor required for establishing the barrier function of the skin. Nat Genet 1999, 22(4):356-360

12. Shields JM, Christy RJ, Yang WW: Identification and characterization of a gene encoding a gut-enriched Kruppel-like factor expressed during growth arrest. J Biol Chem 1996, 271(33):20009-20017.

13. Turner J, Crossley M: Mammalian Kruppel-like transcription factors: more than just a pretty finger. Trends Biochem Sci 1999, 24(6):236-240.

14. Dang DT, Pevsner J, Yang W: The biology of the mammalian Kruppellike family of transcription factors. Int J Biochem Cell Biol 2000, 32(1112):1103-1121.

15. Yet SF, McA'Nulty MM, Folta SC, Yen HW, Yoshizumi M, Hsieh CM, Layne MD, Chin MT, Wang H, Perrella MA, Jain MK, Lee ME: Human EZF, a Kruppel-like zinc finger protein, is expressed in vascular endothelial cells and contains transcriptional activation and repression domains. J Biol Chem 1998, 273(2):1026-1031.

16. Wei D, Gong W, Kanai M, Schlunk C, Wang L, Yao JC, Wu TT, Huang S, Xie K: Drastic down-regulation of Kruppel-like factor 4 expression is critical in human gastric cancer development and progression. Cancer Res 2005, 65(7):2746-2754.

17. Choi BJ, Cho YG, Song JW, Kim CJ, Kim SY, Nam SW, Yoo NJ, Lee JY, Park WS: Altered expression of the KLF4 in colorectal cancers. Pathol Res Pract 2006, 202(8):585-589.

18. Foster KW, Frost AR, McKie-Bell P, Lin CY, Engler JA, Grizzle WE, Ruppert JM: Increase of GKLF messenger RNA and protein expression during progression of breast cancer. Cancer Res 2000, 60(22):6488-6495.

19. Foster KW, Ren S, Louro ID, Lobo-Ruppert SM, McKie-Bell P, Grizzle W, Hayes MR, Broker TR, Chow LT, Ruppert JM: Oncogene expression cloning by retroviral transduction of adenovirus E1A-immortalized rat kidney RK3E cells: transformation of a host with epithelial features by c-MYC and the zinc finger protein GKLF. Cell Growth Differ 1999, 10(6):423-434.

20. McConnell BB, Yang WW: Mammalian Kruppel-like factors in health and diseases. Physiol Rev 2010, 90(4):1337-1381.

21. Pandya AY, Talley LI, Frost AR, Fitzgerald TJ, Trivedi V, Chakravarthy M, Chhieng DC, Grizzle WE, Engler JA, Krontiras H, Bland KI, LoBuglio AF, LoboRuppert SM, Ruppert JM: Nuclear localization of KLF4 is associated with an aggressive phenotype in early-stage breast cancer. Clin Cancer Res 2004, 10(8):2709-2719.

22. Yu F, Li J, Chen H, Fu J, Ray S, Huang S, Zheng H, Ai W: Kruppel-like factor 4 (KLF4) is required for maintenance of breast cancer stem cells and for cell migration and invasion. Oncogene 2011, 30(18):2161-2172. 
23. Bruce SJ, Gardiner BB, Burke LJ, Gongora MM, Grimmond SM, Perkins AC: Dynamic transcription programs during ES cell differentiation towards mesoderm in serum versus serum-freeBMP4 culture. BMC Genomics 2007, 8:365.

24. Zhang P, Andrianakos R, Yang Y, Liu C, Lu W: Kruppel-like factor 4 (KIf4) prevents embryonic stem (ES) cell differentiation by regulating Nanog gene expression. J Biol Chem 2010, 285(12):9180-9189.

25. Takahashi K, Yamanaka S: Induction of pluripotent stem cells from mouse embryonic and adult fibroblast cultures by defined factors. Cell 2006, 126(4):663-676.

26. Wernig M, Meissner A, Foreman R, Brambrink T, Ku M, Hochedlinger $K$ Bernstein $B E$, Jaenisch $R$ : In vitro reprogramming of fibroblasts into a pluripotent ES-cell-like state. Nature 2007, 448(7151):318-324.

27. Park $\mathrm{H}$, Zhao $\mathrm{R}$, West JA, Yabuuchi $\mathrm{A}$, Huo $\mathrm{H}$, Ince $\mathrm{TA}$, Lerou $\mathrm{PH}$, Lensch MW, Daley GQ: Reprogramming of human somatic cells to pluripotency with defined factors. Nature 2008, 451(7175):141-146.

28. Takahashi K, Tanabe K, Ohnuki M, Narita M, Ichisaka T, Tomoda K, Yamanaka S: Induction of pluripotent stem cells from adult human fibroblasts by defined factors. Cell 2007, 131(5):861-872.

29. Yu J, Vodyanik MA, Smuga-Otto K, Antosiewicz-Bourget J, Frane JL, Tian S, Nie J, Jonsdottir GA, Ruotti V, Stewart R, Slukvin II, Thomson JA: Induced pluripotent stem cell lines derived from human somatic cells. Science 2007, 318(5858):1917-1920

30. Misdorp W, Else RW, Hellmén E, Lipscomb TP: Histological Classification of Mammary Tumors of the Dog and Cat. Washington, D. C.: American Registry of Pathology; 1999.

31. Briffod M, Hacene K, Le Doussal V: Immunohistochemistry on cell blocks from fine-needle cytopunctures of primary breast carcinomas and lymph node metastases. Mod Pathol 2000, 13(8):841-850.

32. Charafe-Jauffret E, Tarpin C, Bardou VJ, Bertucci F, Ginestier C, Braud AC, Puig B, Geneix J, Hassoun J, Birnbaum D, Jacquemier J, Viens P: Immunophenotypic analysis of inflammatory breast cancers: identification of an 'inflammatory signature'. J Pathol 2004, 202(3):265-273.

33. Li J, Martinka M, Li G: Role of ING4 in human melanoma cell migration, invasion and patient survival. Carcinogenesis 2008, 29(7):1373-1379.

34. Matos I, Dufloth R, Alvarenga M, Zeferino LC, Schmitt F: p63, cytokeratin 5, and P-cadherin: three molecular markers to distinguish basal phenotype in breast carcinomas. Virchows Arch 2005, 447(4):688-694.

doi:10.1186/1746-6148-7-58

Cite this article as: Chu et al:: Elevated Krüppel-like factor 4 transcription factor in canine mammary carcinoma. BMC Veterinary Research 2011 7:58.

\section{Submit your next manuscript to BioMed Central and take full advantage of:}

- Convenient online submission

- Thorough peer review

- No space constraints or color figure charges

- Immediate publication on acceptance

- Inclusion in PubMed, CAS, Scopus and Google Scholar

- Research which is freely available for redistribution

Submit your manuscript at www.biomedcentral.com/submit 